\title{
Pemetaan Bawah Permukaan dan Analisis Tektonostratigrafi, Blok Ariati, Cekungan Jawa Timur
}

\author{
Vydia Ridha Ariati ${ }^{\left.1{ }^{*}\right)}$, Fahrudin ${ }^{1}$, Ahmad Syauqi Hidayatillah ${ }^{1}$, Rizzasila Widiartha $^{2}$ \\ ${ }^{1}$ Departemen Teknik Geologi, Fakultas Teknik, Universitas Diponegoro, Semarang \\ ${ }^{2}$ Pertamina Hulu Energi Nunukan Company
}

\begin{abstract}
Abstrak
Cekungan Jawa Timur adalah salah satu cekungan minyak dan gas bumi di Indonesia. Analisis tektonostratigrafi pada cekungan ini dilakukan untuk mengetahui kontrol tektonik terhadap pengendapan yang terjadi melalui pemetaan bawah permukaan. Penelitian ini dilakukan dengan menggunakan metode deskriptif analitis dengan data yang digunakan adalah data sumur, data checkshot, data cutting, data core, dan data penampang seismik 2D. Pada sumur VRA-1 terbagi menjadi 4 formasi, sedangkan pada sumur VRA-2 terbagi menjadi 2 formasi. Sikuen stratigrafi dan lingkungan pengendapan diinterpretasi dari masing-masing formasi. Formasi Kujung dan Formasi Tuban Karbonat terendapkan di isolated platform, Formasi Tuban Shale terendapkan di isolated platform, Formasi Ngrayong terendapkan di shelf, dan Formasi Wonocolo terendapkan di deep marine. Pada daerah penelitian ditemukan sesar inversi dan sesar naik dengan arah relatif timur-barat mengikuti Pola Sakala. Struktur ini mempengaruhi pengendapan Blok Ariati, Cekungan Jawa Timur. Secara tektonostratigrafi, daerah penelitian terdiri dari tiga fase. Fase pertama adalah fase prerift yang menghasilkan batuan dasar. Fase kedua adalah fase synrift yang menghasilkan unit batuan karbonat (Formasi Kujung dan Formasi Tuban Karbonat). Sedangkan fase ketiga adalah fase postrift atau syninversion yang menghasilkan Formasi Tuban Shale, Formasi Ngrayong, dan Formasi Wonocolo.
\end{abstract}

Kata kunci: Analisis Tektonostratigrafi; Cekungan Jawa Timur; Pemetaan Bawah Pemukaan.

\begin{abstract}
East Java Basin is one of the oil and gas basins in Indonesia. The tectonostratigraphy analysis was conducted to determine the tectonic control of sedimentation through the subsurface mapping. The method is a descriptive-analytical method that consists of well data, checkshot, cutting, core, and $2 D$ seismic cross-sectional data. The VRA-1 well is divided into 4 formations, while the VRA-2 well is 2 formations. Sequence stratigraphy and depositional environment were interpreted from each formation. The Kujung Formation and Tuban Carbonate Formation were deposited on the isolated platforms, Tuban Shale Formation on the isolated platform, Ngrayong Formation in the shelf, and Wonocolo Formation in deep marine. There is an inversion fault and reverse fault with a relatively east-west direction following the Sakala Pattern found in this area. Those structures affected the deposition of Ariati Block, East Java Basin. In conclusion, based on tectonostratigraphy, the research area consists of three phases. The first phase is the pre-rift phase that produced the basement. The second phase is the syn-rift phase that produced carbonate rock units. Whereas the third phase is the post-rift phase or syn-inversion that produced Tuban Shale, Ngrayong, and Wonocolo Formation.
\end{abstract}

Keywords: Tectonostratigraphy Analysis; East Java Basin; Subsurface Mapping.

\section{PENDAHULUAN}

Cekungan Jawa Timur adalah extensional inversion basin dengan karakteristik basement yang berbeda. Basement cekungan ini adalah hasil tumbukan dari zona transisi Sundaland dengan mikrokontinen Gondwana pada Late Cretaceous (Fahrudin, dkk., 2018). Cekungan Jawa Timur adalah salah satu cekungan minyak dan gas bumi di Indonesia. Cekungan Jawa Timur merupakan salah satu dari cekungan awal di Indonesia yang telah dieksplorasi sejak akhir tahun 1800. Cekungan ini telah dieksplorasi selama 130 tahun, telah memproduksi minyak dan gas selama 114 tahun, dan hingga saat ini, Cekungan Jawa Timur masih sangat menarik untuk dieksplorasi. Cekungan ini merupakan

*) Korespondensi : vydiaridha@gmail.com 
"titik panas" untuk eksplorasi hidrokarbon di Indonesia (Satyana dan Purwaningsih, 2003).

Cekungan Jawa Timur berlokasi di batas tenggara dari Sundaland. Cekungan Jawa Timur memiliki sejarah geodinamik yang aktif. Cekungan ini berubah dari oceanic basin yang berlokasi di sebelah selatan dari zona subduksi di Kapur Akhir, hingga saat ini cekungan ini menjadi back-arc basin yang berada di utara dari busur vulkanik. Terdapat tiga konfigurasi struktural utama dari utara ke selatan yaitu: Northern Platform, Central Deep, dan Southern Uplift (Satyana dan Purwaningsih, 2003). Tektonik regional dari Jawa Timur mendukung adanya bukti tumbukan antara micro-plate dan Sundaland. Tumbukan ini diperkirakan dimulai dari Kapur Akhir hingga Eosen Tengah. Dua arah struktur mayor yang ditemukan di daerah Jawa Timur adalah: E-W Sakala Trend dan NESW Meratus Trend. Berdasarkan stratigrafi dan umur tertua dari pengendapan satuan sedimentasi di cekungan, diketahui bahwa umur Sakala Trend sedikit lebih tua dibanding Meratus Trend (Sribudiyani dkk., 2003). Basement dari Cekungan Jawa Timur terbagi menjadi beberapa horst dan graben yang berarah NE-SW. Basement yang terbagi ini mengakomodasi pengendapan dari sedimen synrift dan postrift berumur Paleogen dan mengakomodasi perkembangan dari karbonat (Satyana dan Purwaningsih, 2003).

Pengetahuan yang lebih baik mengenai karakteristik cekungan sangat penting sebelum melakukan eksplorasi (Sribudiyani dkk., 2003). Dalam mempelajari karakteristik suatu cekungan, dapat dilakukan analisis berupa analisis tektonostratigrafi. Analisis ini dilakukan untuk mengetahui pengaruh tektonisme suatu cekungan terhadap pengendapan sedimen yang mengisi cekungan tersebut.

\section{METODOLOGI}

Metode yang diaplikasikan pada penelitian pada umumnya merupakan analisis menggunakan data sekunder. Analisis dilakukan dengan mengoperasikan software Petrel 2009 yang dapat menampilkan log-log sumur dan penampang seismik.

\section{Analisis Kualitatif Data Sumur}

Metode analisis ini dilakukan untuk mengetahui litologi yang menyusun Blok Ariati, Cekungan Jawa Timur berdasarkan dua sumur, yaitu VRA-
1 dan VRA-2. Penentuan litologi penyusun pada penelitian ini berdasarkan pada karakteristik penyusun litologi.Data sumur yang dipakai dalam analisis ini adalah wireline log, mencakup log gamma ray (GR), log spontaneous potential (SP), log resistivitas, log densitas, log neutron, $\log$ sonic, dan log photoelectron, serta data cutting dan core.

\section{Analisis Sikuen Stratigrafi}

Data yang digunakan antara lain data wireline log, cutting, dan core. Data sumur digunakan untuk mengetahui elektrofasies dari stratigrafi. Elektrofasies ini dilihat dari kecenderungan pola dari log Gamma Ray. Data interpretasi elektrofasies kemudian dilengkapi dengan data jenis litologi beserta karakteristiknya dari data cutting dan data core untuk mendapatkan interpretasi lingkungan pengendapan.

\section{Analisis Seismik Stratigrafi}

Seismik stratigrafi diperlukan untuk mengetahui kondisi geologi di bawah permukaan berdasarkan karakteristik reflektor seismik pada penampang seismik 2D. Analisis ini diawali dengan well seismic tie untuk menentukan kedalaman formasi pada penampang seismik. Selanjutnya dilakukan picking struktur geologi, serta horizon yang diperoleh dari data sumur. Masing-masing horizon kemudian dibuat peta struktur kedalaman dan peta isochore.

\section{Analisis Tektonostratigrafi}

Pengaruh struktur geologi dalam proses pengendapan sedimen di daerah penelitian dilakukan dengan menganalisis hasil peta isochore masing-masing formasi batuan.

\section{HASIL}

\section{Litologi Penyusun}

Pada sumur VRA-1 ditemukan 4 formasi batuan (Gambar 1 (a)), yaitu Formasi Tuban Karbonat, Formasi Tuban Shale, Formasi Ngrayong, dan Formasi Wonocolo.

Formasi pertama ditunjukkan pada kedalaman $2.584 \mathrm{~m}$ MD. Wireline $\log$ pada kedalaman ini menunjukkan karakteristik batugamping, sesuai dengan cutting dan core berupa batugamping masif. Batugamping ini terdiri dari foraminiferal packstones dan wackestones dengan mudstones, rudstones, serta algal boundstones. Formasi ini diinterpretasikan ekuivalen dengan Formasi Tuban Karbonat. 

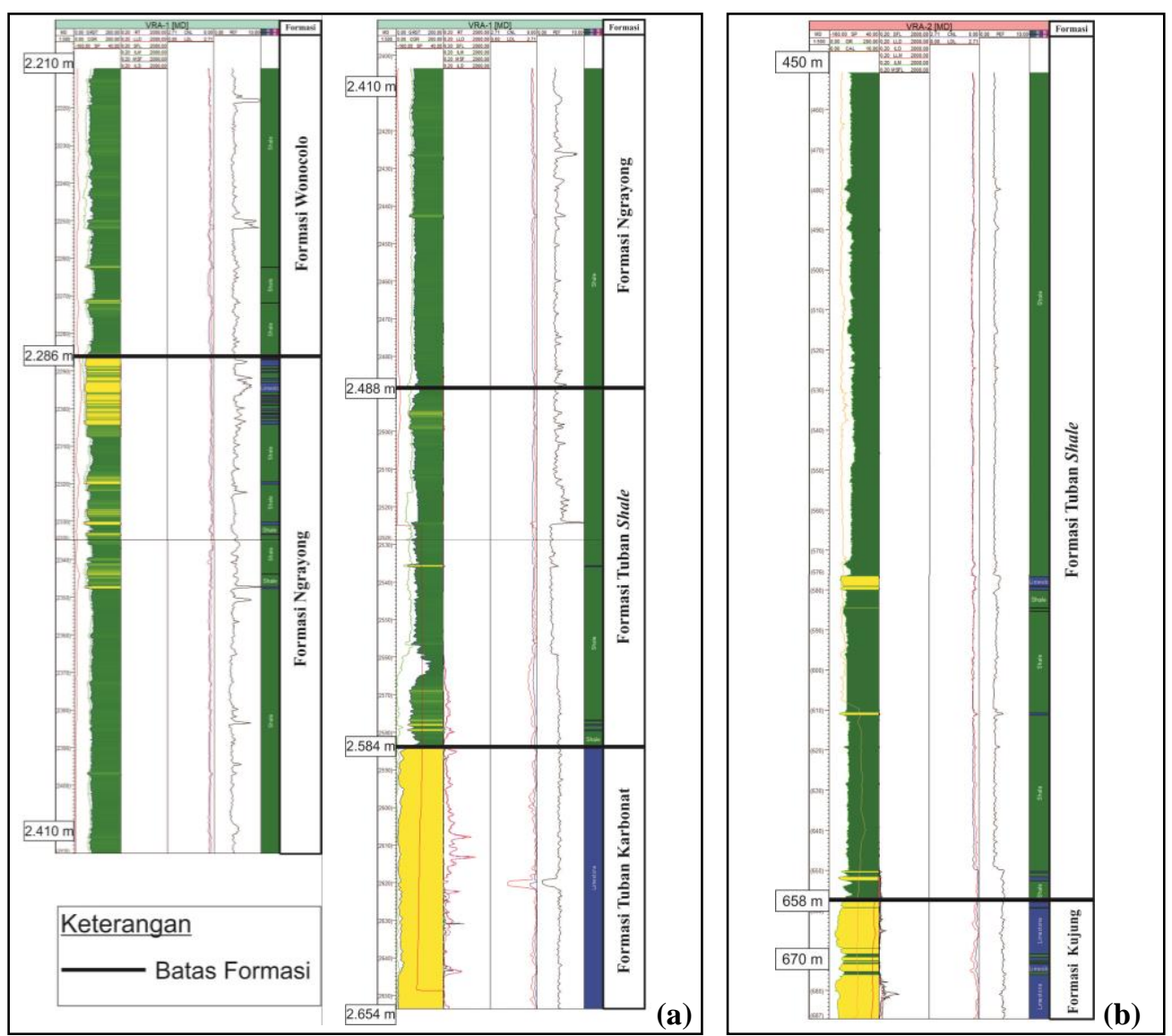

Gambar 1. Identifikasi Formasi Sumur (a) VRA-1 (b) VRA-2.

Formasi kedua ditunjukkan pada kedalaman sekitar $2.488 \mathrm{~m}$ MD hingga $2.584 \mathrm{~m}$ MD. Wireline $\log$ pada kedalaman ini menunjukkan adanya batulempung dengan sisipan lapisan batupasir dan batugamping. Berdasarkan data cutting dan data core, interval ini tersusun dari batulempung yang didasari oleh batugamping yang masif. Formasi ini diinterpretasikan merupakan ekuivalen dari batas atas Formasi Tuban Shale.

Formasi ketiga ditunjukkan pada kedalaman sekitar $2.286 \mathrm{~m}$ MD hingga $2.488 \mathrm{~m}$ MD. Wireline log pada kedalaman ini menunjukkan adanya perselingan litologi batulempung, batupasir, dan batugamping. Data cutting dan data core dari kedalaman ini menunjukkan batulempung dengan lapisan tipis batupasir, lapisan tipis batugamping, serta dolomit. Formasi ini diinterpretasikan merupakan ekuivalen dari batas atas Formasi Ngrayong.

Formasi keempat ditunjukkan pada kedalaman sekitar $2.210 \mathrm{~m}$ MD hingga $2.286 \mathrm{~m}$ MD. Wireline $\log$ pada kedalaman ini menunjukkan adanya litologi batulempung.
Berdasarkan data cutting dan data core, pada kedalaman ini terdapat litologi batulempung dengan sisipan batugamping, batulanau, dan lapisan tipis batupasir sangat halus. Formasi ini diinterpretasikan merupakan ekuivalen dari batas atas Formasi Wonocolo.

Pada sumur VRA-2 ditemukan 2 formasi (Gambar 1 (b)). Formasi tersebut antara lain Formasi Kujung dan Formasi Tuban Shale. Formasi pertama ditunjukkan pada kedalaman di bawah $658 \mathrm{~m}$ MD. Wireline log pada kedalaman ini menunjukkan karakteristik batugamping. Berdasarkan data cutting dan data core, interval ini tersusun oleh batugamping. Batugamping pada formasi ini terdiri dari packstones, wackestones, mudstones, grainstones, chalky carbonate, dan crystalline carbonate. Formasi ini diinterpretasikan ekuivalen dengan batas atas Formasi Kujung.

Formasi kedua berada pada kedalaman di atas $658 \mathrm{~m}$ MD. Wireline log pada kedalaman ini menunjukkan adanya litologi batulempung. Berdasarkan data cutting dan data core, pada kedalaman ini dijumpai batulempung dengan 
lapisan tipis batugamping, dan lapisan batupasir lanauan yang jarang. Formasi ini diinterpretasikan merupakan ekuivalen dari Formasi Tuban Shale.

\section{Analisis Seismik Stratigrafi Data Penampang Seismik 2D}

Di penelitian, terdapat dua formasi yang memiliki litologi berupa batuan karbonat yaitu Formasi Kujung dan Formasi Tuban Karbonat.
Formasi ini memiliki kedalaman yang jauh berbeda pada kenampakan penampang seismik 2D, namun saat dilakukan flattening pada horizon Tuban Shale dapat dilihat bahwa kedua formasi ini berada pada kedalaman yang sama sehingga diinterpretasikan batugamping penyusun Formasi Kujung berkembang menerus hingga umur Formasi Tuban (Gambar 2). Oleh karena itu, kedua formasi ini disetarakan menjadi unit batuan karbonat.

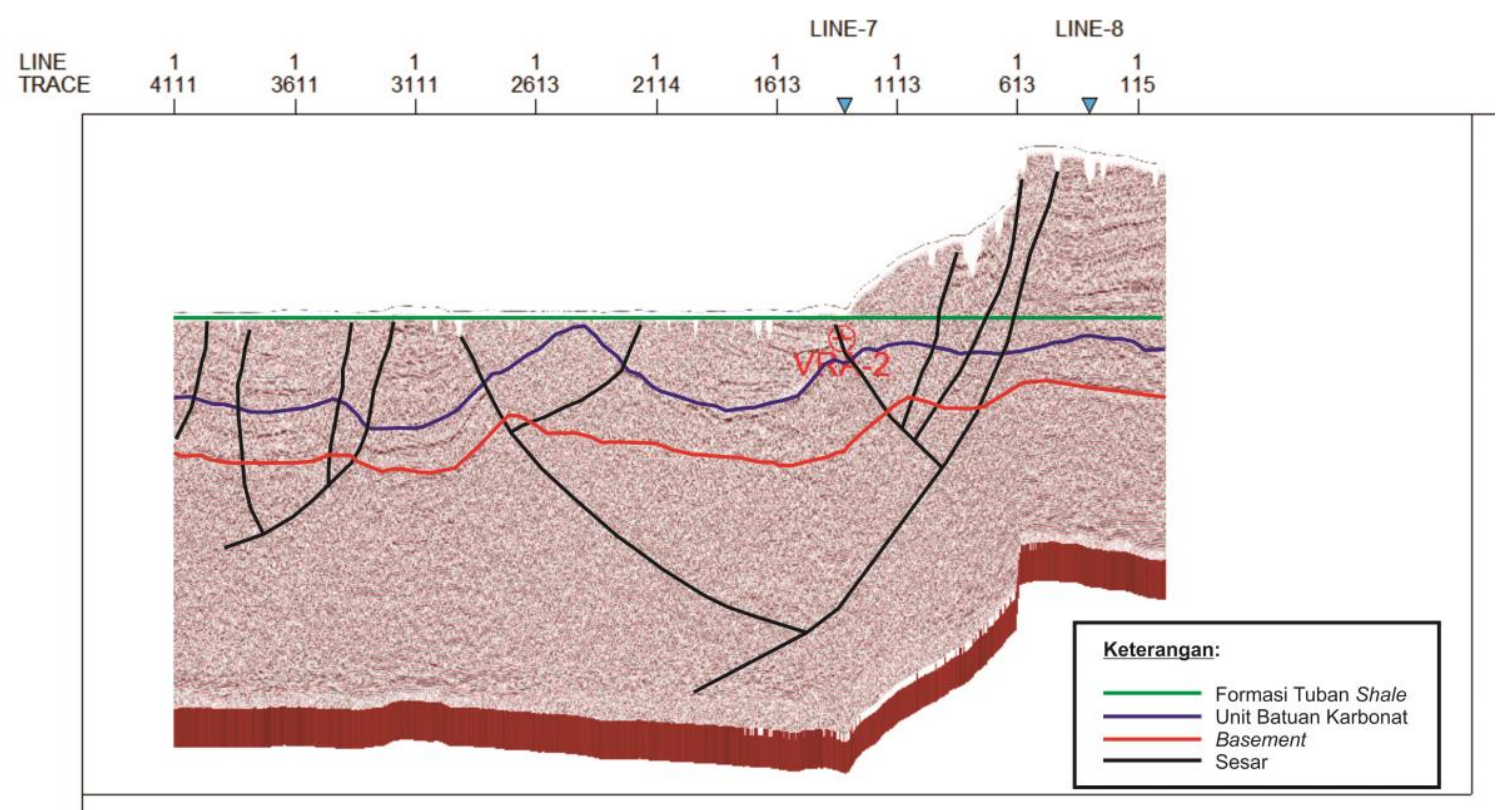

Gambar 2. Unit Batuan Karbonat dengan flattening Formasi Tuban Shale pada Line-1.

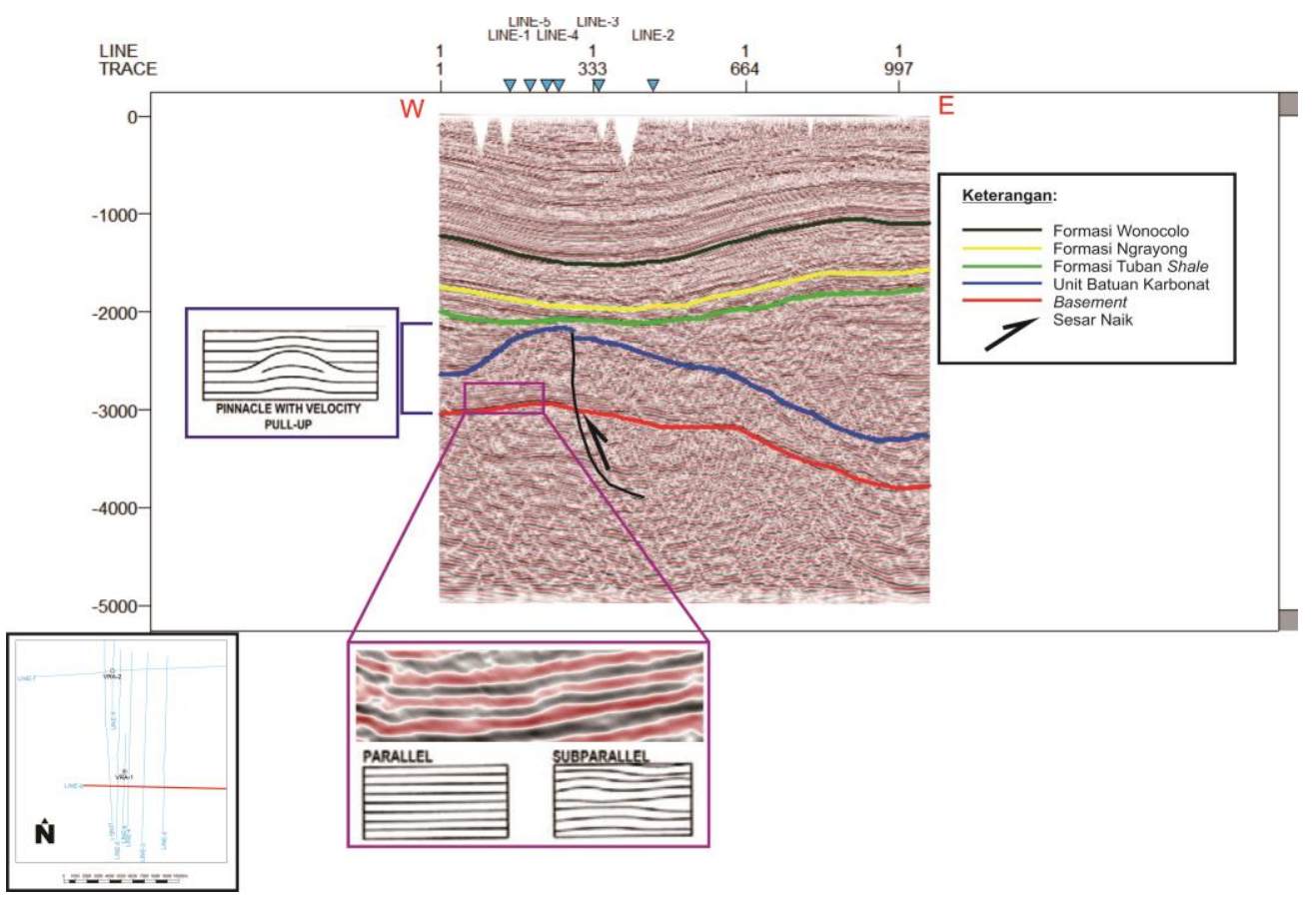

Gambar 3. Konfigurasi Seismik Unit Batuan Karbonat Line-8 


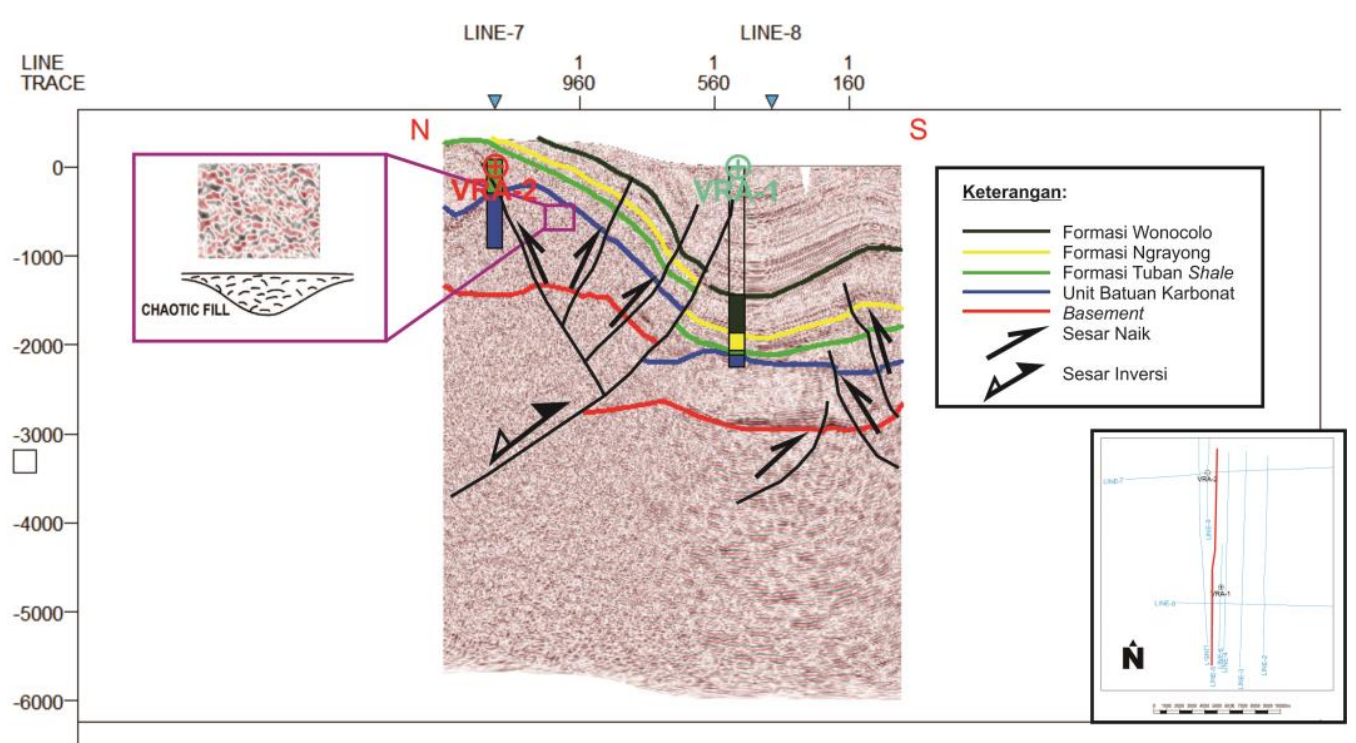

Gambar 4. Konfigurasi Seismik Unit Batuan Karbonat Line-5

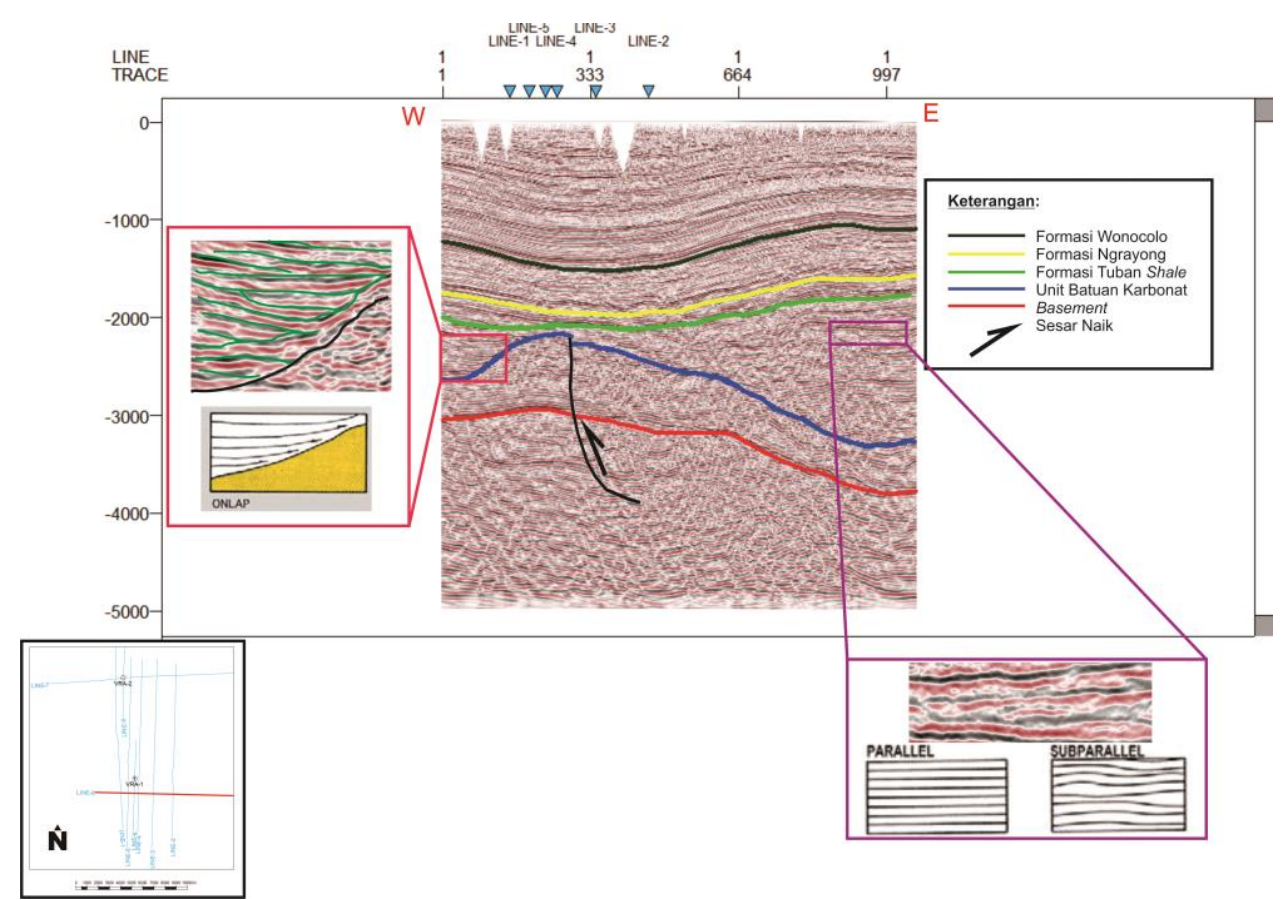

Gambar 5. Konfigurasi Seismik Formasi Tuban Shale Line-8

Unit batuan karbonat memiliki batas bawah yang ditentukan oleh seismik stratigrafi yaitu dengan adanya perbedaan konfigurasi penampang seismik 2D antara unit ini dengan unit dibawahnya. Batas atas pada unit batuan karbonat ditentukan oleh data sumur dan seismik stratigrafi. Berdasarkan data seismik stratigrafi, unit batuan karbonat dibatasi oleh adanya onlap dari unit diatasnya. Unit batuan karbonat memiliki konfigurasi internal berupa parallelsubparallel dan chaotic serta memiliki bentuk eksternal berupa mound yang menunjukkan bentuk carbonate build up (Gambar 3 dan 4).
Formasi Tuban Shale memiliki batas bawah yang ditentukan oleh data sumur dan seismik stratigrafi yaitu dibatasi oleh adanya onlap. Batas atas pada unit Formasi Tuban Shale ditentukan oleh data sumur. Formasi Tuban Shale memiliki konfigurasi internal berupa parallel-subparallel dan sigmoid (Gambar 5 dan 6). Formasi Ngrayong memiliki batas bawah dan batas atas yang ditentukan oleh data sumur. Formasi Ngrayong memiliki konfigurasi internal berupa parallel-subparallel (Gambar 7).

Formasi Wonocolo memiliki batas bawah dan batas atas yang ditentukan oleh data sumur. 
Formasi Wonocolo memiliki konfigurasi internal berupa parallel-subparallel (Gambar 8).

\section{Analisis Sikuen Stratigrafi dan Lingkungan Pengendapan}

Pada data log sumur VRA-1 dapat ditemukan tujuh sistem tract yang dapat dilihat berdasarkan pola elektrofasies (Gambar 9 (a)). Sistem tract pertama dibatasi oleh adanya batas transgresive surface 1 (TS1). Litologi di bawah batas sistem tract ini adalah litologi batugamping masif yang terdiri dari foraminiferal packstones dan wackestones dengan mudstones, rudstones, dan algal boundstones. Sistem tract ini memiliki pola elektrofasies cylindrical dengan fase keep up carbonate dan diinterpretasikan terendapkan pada lingkungan pengendapan isolated platform. Pada sistem tract ini diinterpretasikan termasuk ke dalam lowstand system tract (LST).

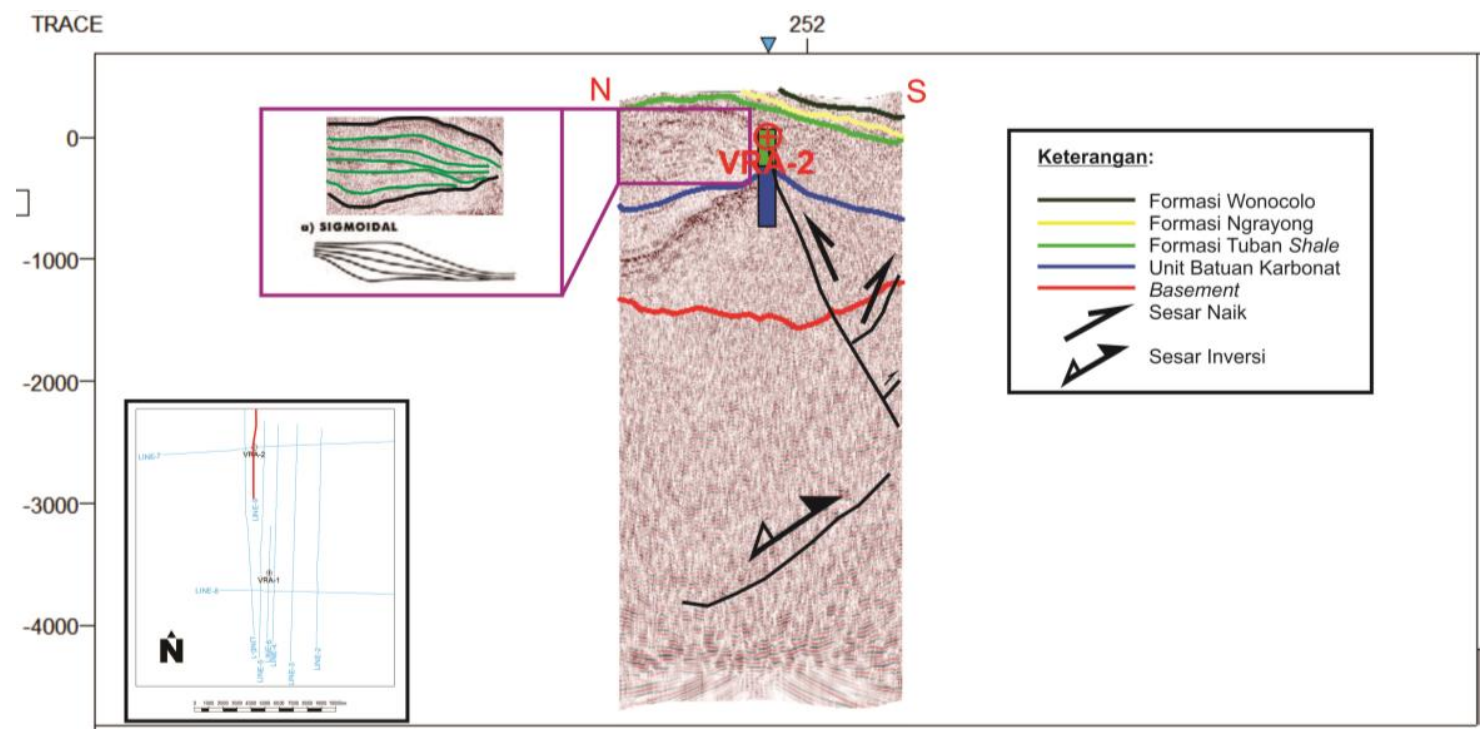

Gambar 6. Konfigurasi Seismik Formasi Tuban Shale Line-9

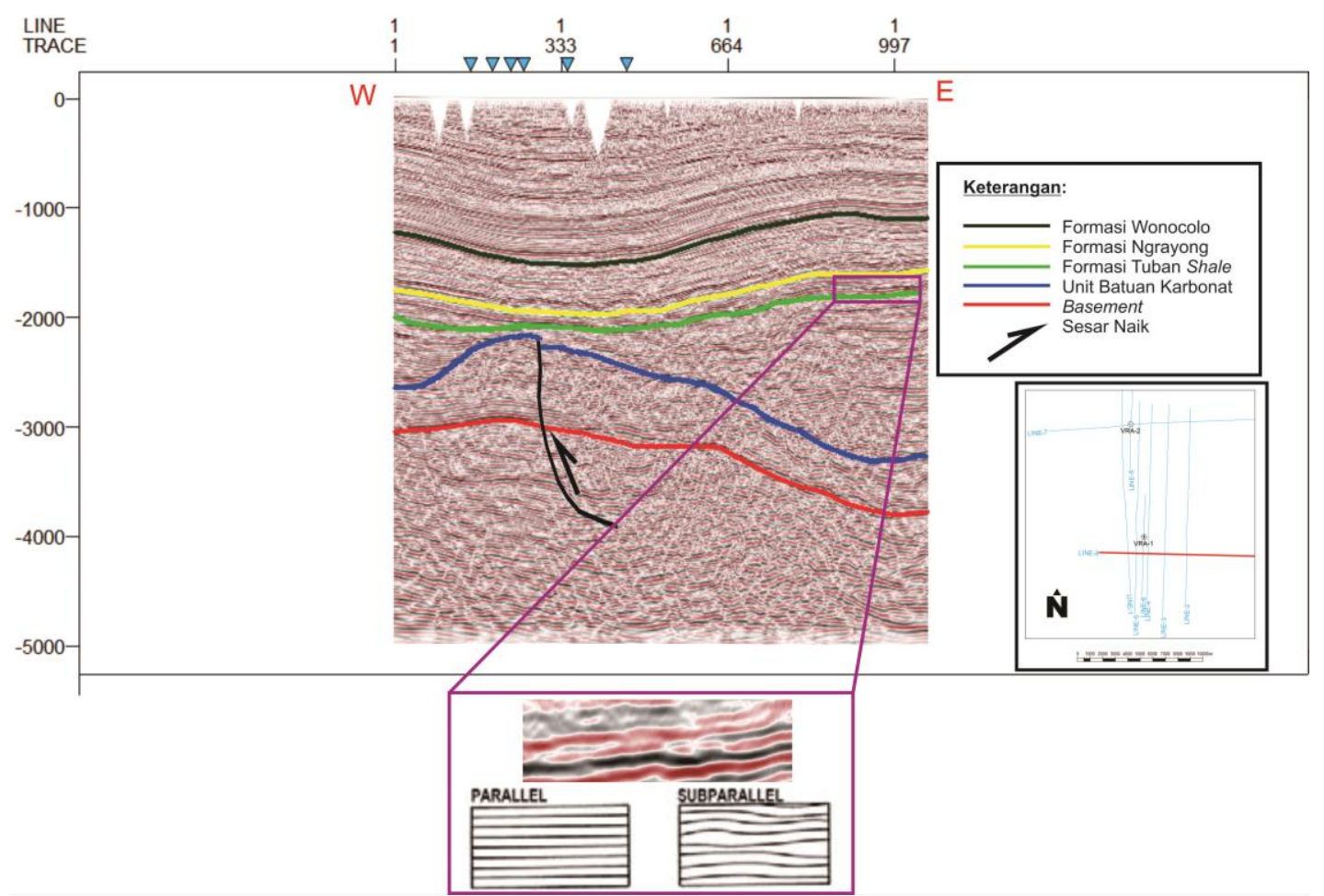

Gambar 7. Konfigurasi Seismik Formasi Ngrayong Line-8 


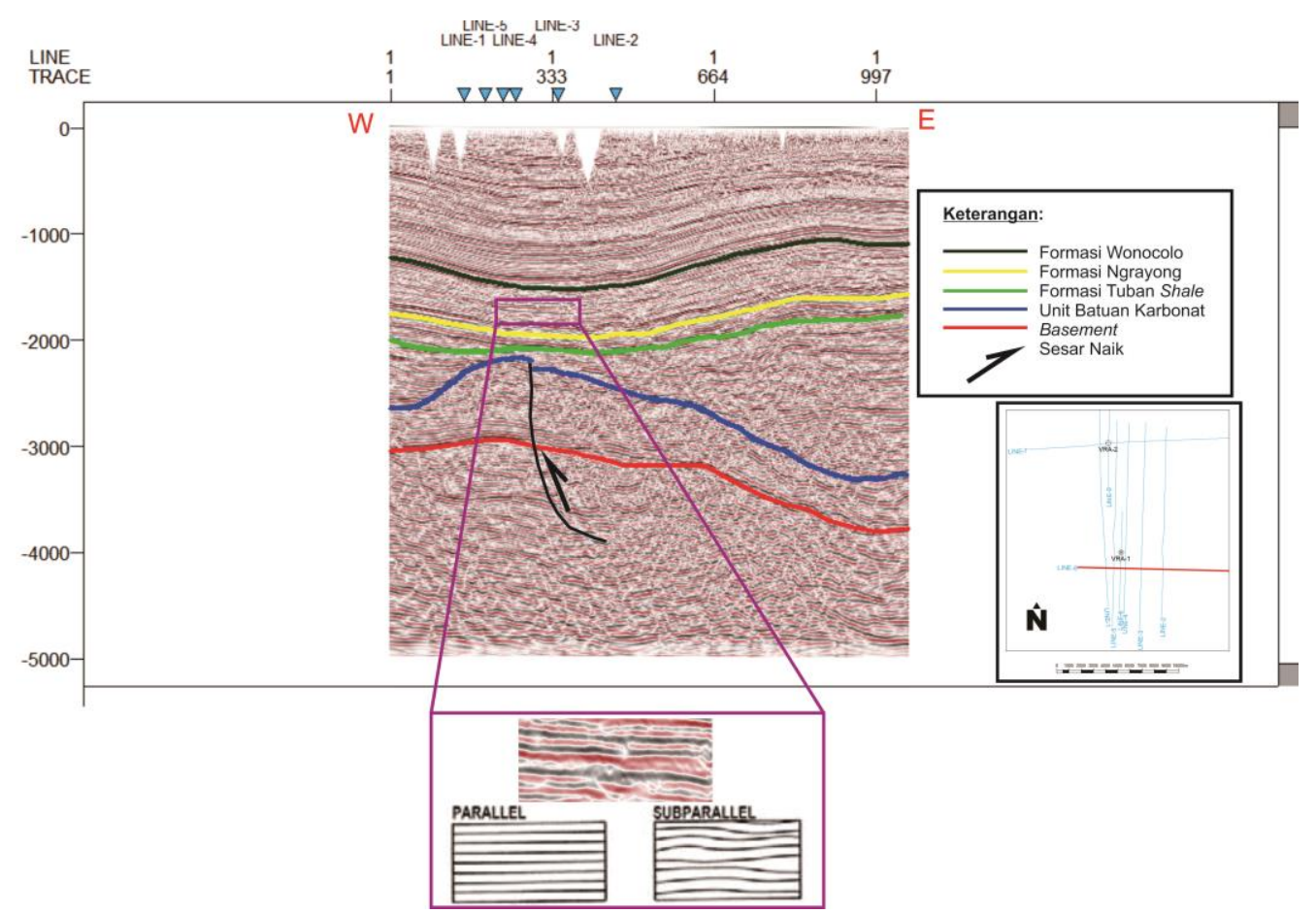

Gambar 8. Konfigurasi Seismik Formasi Wonocolo Line-8.

Sistem tract kedua dibatasi oleh adanya batas flooding surface 1 (FS1). Litologi di bawah batas sistem tract ini adalah litologi batulempung dengan sisipan lapisan batupasir dan batugamping. Sistem tract ini memiliki pola elektrofasies symmetrical dengan fasies reworked offshore bar dan diinterpretasikan terendapkan pada lingkungan pengendapan isolated platform. Pada sistem tract ini diinterpretasikan termasuk ke dalam transgressive system tract (TST).

Sistem tract ketiga dibatasi oleh adanya batas sequence boundary 1 (SB1). Litologi di bawah batas sistem tract ini adalah litologi batulempung dengan sisipan lapisan batupasir dan batugamping. Sistem tract ini memiliki pola elektrofasies funnel dengan fasies shoreface dan diinterpretasikan terendapkan pada lingkungan pengendapan isolated platform. Pada sistem tract ini diinterpretasikan termasuk ke dalam highstand system tract (HST).

Sistem tract keempat dibatasi oleh adanya batas maximum flooding surface 1 (MFS1). Litologi di bawah batas sistem tract ini adalah litologi batulempung yang tebal. Sistem tract ini memiliki pola elektrofasies cylindrical dengan fasies carbonate-shelf margin dan diinterpretasikan terendapkan pada lingkungan pengendapan shelf. Pada sistem tract ini diinterpretasikan termasuk ke dalam transgressive system tract (TST).

Sistem tract kelima dibatasi oleh adanya batas sequence boundary 2 (SB2). Litologi di bawah batas sistem tract ini adalah litologi batulempung dengan sedikit lapisan batupasir dan batugamping. Sistem tract ini memiliki dua pola elektrofasies yaitu serrated dengan fasies storm-dominated shelf dan funnel dengan fasies change from clastic to carbonates. Sistem tract ini diinterpretasikan terendapkan pada lingkungan pengendapan shelf. Dan diinterpretasikan termasuk ke dalam highstand system tract (HST).

Sistem tract keenam dibatasi oleh adanya batas transgresive surface 2 (TS2). Litologi di bawah batas sistem tract ini adalah litologi batugamping, batupasir, dan batulempung. Sistem tract ini memiliki pola elektrofasies cylindrical dengan fasies carbonate shelf margin dan diinterpretasikan terendapkan pada lingkungan pengendapan shelf. Pada sistem tract ini diinterpretasikan termasuk ke dalam lowstand system tract (LST).

Sistem tract ketujuh dibatasi oleh adanya batas batas transgresive surface 2 (TS2). Litologi di atas batas sistem tract ini adalah litologi batulempung dengan sisipan lapisan batupasir dan batugamping. Sistem tract ini memiliki pola elektrofasies serrated dengan 

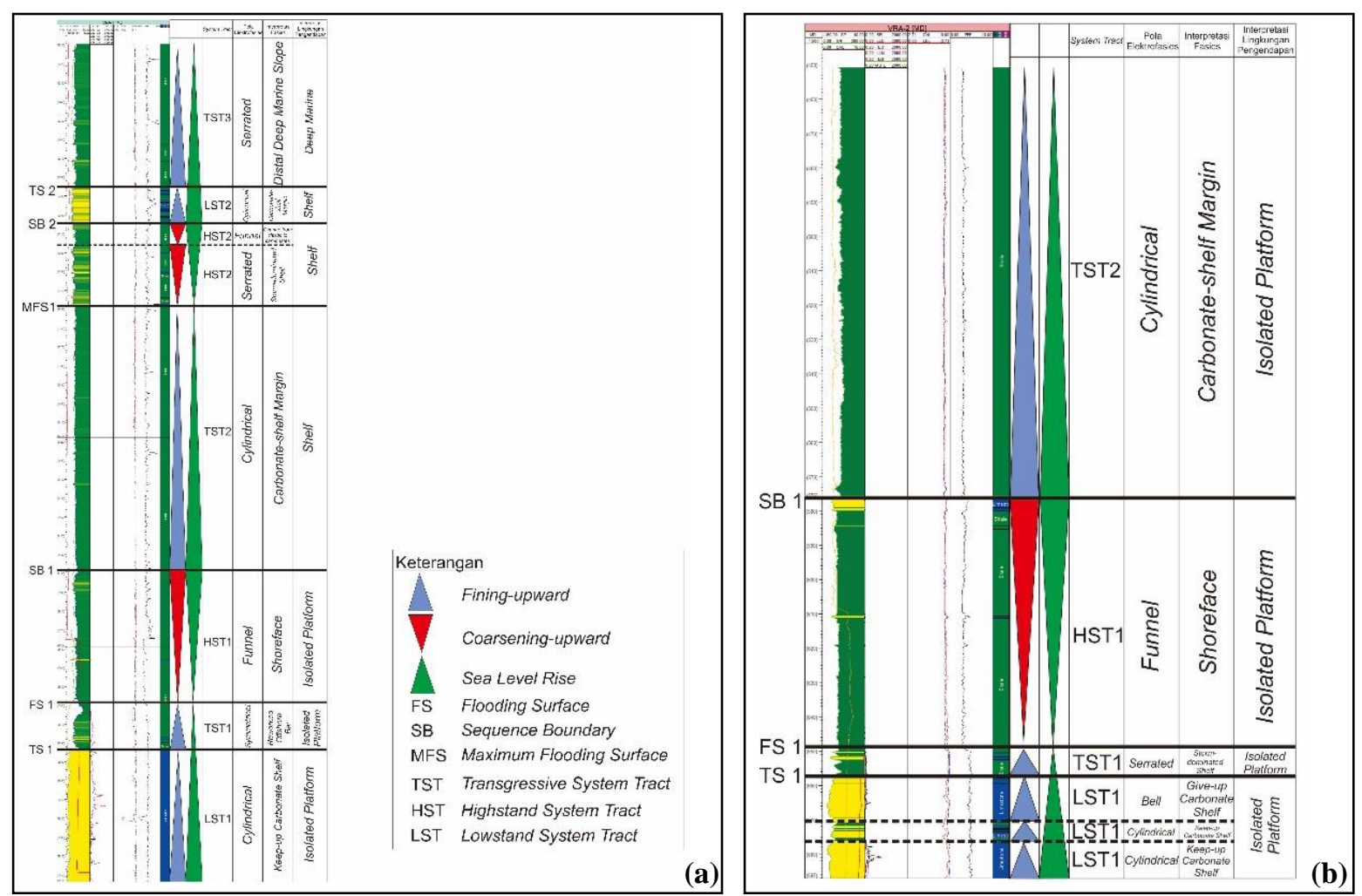

Gambar 9. Interpretasi Sikuen Stratigrafi (a) Sumur VRA-1 (b) Sumur VRA-2

fasies distal deep marine slope dan diinterpretasikan terendapkan pada lingkungan pengendapan deep marine. Pada sistem tract ini diinterpretasikan termasuk ke dalam transgressive system tract (TST).

Pada data log sumur VRA-2 dapat ditemukan empat sistem tract yang dapat dilihat berdasarkan pola elektrofasies (Gambar 9 (b)). Sistem tract pertama dibatasi oleh adanya batas transgresive surface 1 (TS1). Litologi di bawah batas sistem tract ini adalah litologi batugamping masif yang terdiri dari packstones, wackestones, mudstones, grainstones, chalky carbonate, dan crystalline carbonate. Sistem tract ini terdiri dari tiga bagian yang memiliki pola elektrofasies cylindrical, cylindrical, serta bell yang diinterpretasikan terendapkan pada lingkungan pengendapan isolated platform. Pada sistem tract ini diinterpretasikan termasuk ke dalam lowstand system tract (LST).

Sistem tract kedua dibatasi oleh adanya batas flooding surface 1 (FS1). Litologi di bawah batas sistem tract ini adalah litologi batulempung dengan sisipan lapisan batupasir dan batugamping. Sistem tract ini memiliki pola elektrofasies serrated dengan fasies storm dominated shelf dan diinterpretasikan terendapkan pada lingkungan pengendapan isolated platform. Pada sistem tract ini diinterpretasikan termasuk ke dalam transgressive system tract (TST).

Sistem tract ketiga dibatasi oleh adanya batas sequence boundary 1 (SB1). Litologi di bawah batas sistem tract ini adalah litologi batulempung dengan sisipan lapisan batupasir dan batugamping. Sistem tract ini memiliki pola elektrofasies funnel dengan fasies shoreface dan diinterpretasikan terendapkan pada lingkungan pengendapan isolated platform. Pada sistem tract ini diinterpretasikan termasuk ke dalam highstand system tract (HST).

Sistem tract keempat dibatasi oleh adanya batas sequence boundary 1 (SB1). Litologi di atas batas sistem tract ini adalah litologi batulempung yang tebal. Sistem tract ini memiliki pola elektrofasies cylindrical dengan fasies carbonate-shelf margin dan diinterpretasikan terendapkan pada lingkungan pengendapan isolated platform. Pada sistem tract ini diinterpretasikan termasuk ke dalam transgressive system tract (TST). 


\section{PEMBAHASAN}

\section{Struktur Geologi}

Proses tektonik pada Blok Ariati, Cekungan Jawa Timur telah menghasilkan deformasi batuan yang terlihat sebagai struktur geologi. Berdasarkan data penampang seismik 2D, ditemukan struktur geologi berupa sesar. Kenampakan struktur sesar pada seismik ini ditunjukkan oleh ketidakmenerusan lapisan, reflektor seismik secara lateral terputus dan bergeser.

Pada daerah penelitian, sesar yang ditemukan adalah sesar yang bergerak searah dengan kemiringan bidang sesar atau sering disebut dipslip fault. Sesar yang terdapat pada daerah penelitian ini diidentifikasikan sebagai sesar naik. Terdapat 6 sesar yang ditemukan pada daerah penelitian yaitu, Fault 1 (sesar inversi), Fault 2, Fault 3, Fault 4, Fault 5, dan Fault 6. Deformasi yang terjadi akibat sesar ini melibatkan batuan dasar dan bukan hanya lapisan sedimen diatasya. Oleh karena itu, sesar pada daerah penelitian ini disebut bersifat thickskinned. Struktur yang terdapat pada Blok Ariati ini memiliki arah timur-barat atau mengikuti pola Sakala (Gambar 10).

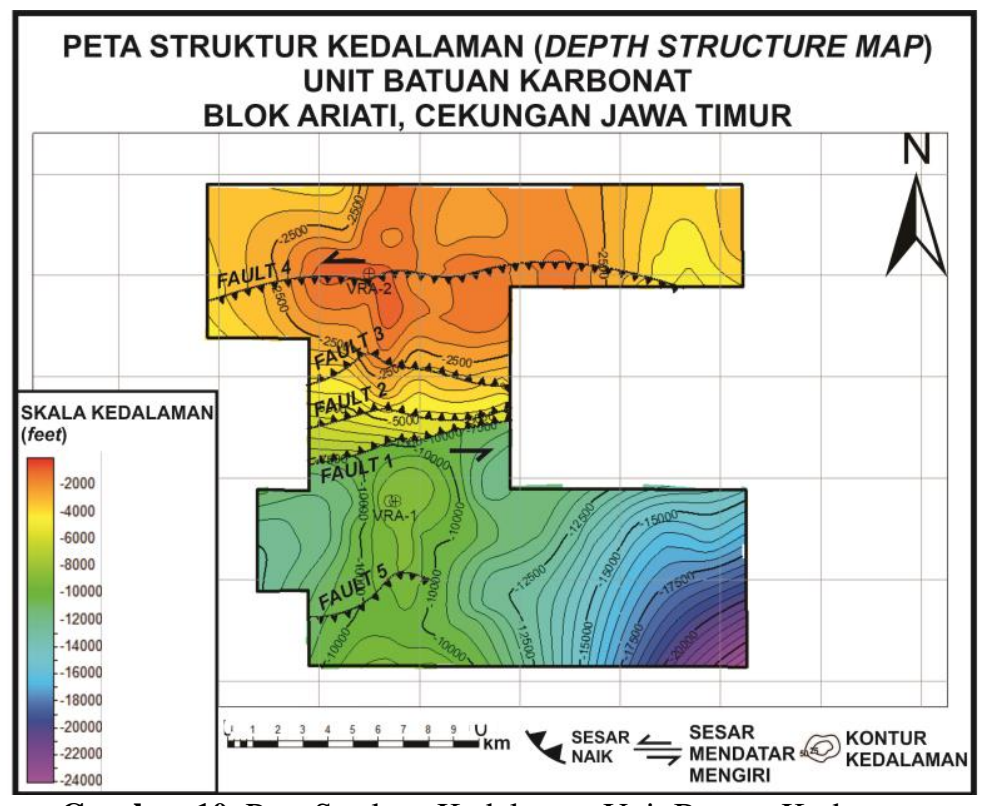

Gambar 10. Peta Struktur Kedalaman Unit Batuan Karbonat

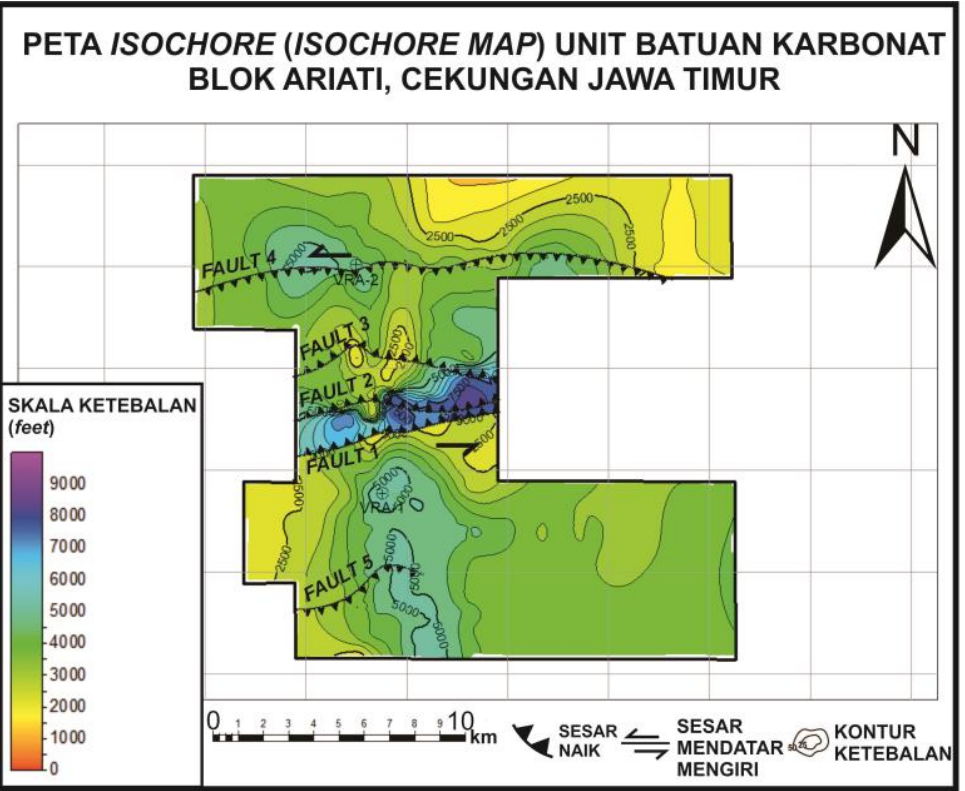

Gambar 11. Peta Isochore Unit Batuan Karbonat 


\section{Tektonostratigrafi}

Fase prerift terjadi sebelum adanya fase ekstensional berupa rifting. Pada daerah penelitian rifting terjadi pada umur Paleogen. Hal ini mengindikasikan bahwa fase prerift terjadi sebelum umur Paleogen tersebut atau dapat disebut Pra-Paleogen. Menurut Bransden, dkk(1992), fase prerift adalah zona akresi yang disebabkan oleh kolisi antara Lempeng Mikro Laut Jawa Timur dengan Lempeng Eurasia bagian tenggara pada Kapur Akhir. Litologi yang termasuk kedalam fase prerift pada daerah penelitian ini adalah batuan dasar atau basement berupa batuan metamorf. Litologi ini menunjukkan kenampakan chaotic pada penampang seismik 2D. Kenampakan chaotic disebabkan oleh densitas yang tinggi sehingga susah terbaca oleh seismik.

Pada fase synrift, analisis geometri endapan synrift adalah hal yang dilakukan untuk mengetahui tektonostratigrafi pada daerah penelitian. Geometri endapan synrift pada Blok Ariati, Cekungan Jawa Timur dapat dilihat melalui data peta isochore formasi yang diinterpretasikan terbentuk saat terjadinya fase synrift yaitu unit batuan karbonat yang terdiri dari Formasi Kujung dan Formasi Tuban Karbonat (Gambar 11).

Pada daerah penelitian terlihat terdapat sesar yang mempengaruhi proses sedimentasi. Hal ini dilihat dari adanya pola penebalan yang terjadi ke arah bidang sesar yaitu pada sesar Fault 1. Fault 1 memiliki arah timur-barat yang relatif sama dengan arah dari pola struktur Sakala. Sesar ini mempengaruhi geometri endapan synrift di daerah penelitian. Berdasarkan peta isochore terlihat terdapat perbedaan ketebalan yang awalnya tipis di bagian utara, lalu menebal, dan kemudian berubah menjadi tipis kembali di selatan peta. Perbedaan ketebalan lapisan pada fase synrift disebabkan karena sedimen mengisi cekungan yang terbentuk akibat sesar yang terus bergerak. Perbedaan ketebalan ini dibatasi oleh sesar pembatas (border fault) yaitu Fault 1. Adanya pola penebalan di peta isochore unit batuan karbonat membuktikan bahwa unit tersebut benar termasuk dalam fase synrift.

Pada fase postrift atau syn-inversion, analisis geometri endapan postrift atau syn-inversion adalah hal yang dilakukan untuk mengetahui tektonostratigrafi pada daerah penelitian. Geometri endapan postrift atau syn-inversion pada Blok Ariati, Cekungan Jawa Timur dapat dilihat melalui data peta isochore formasi yang diinterpretasikan terbentuk saat terjadinya fase postrift atau syn-inversion yaitu Formasi Tuban Shale, Formasi Ngrayong, dan Formasi Wonocolo (Gambar 12 dan 13).

Pada daerah penelitian dapat terlihat bahwa berdasarkan peta isochore tidak terlihat adanya perbedaan ketebalan, ditandai dengan warna kontur yang cenderung sama pada peta.

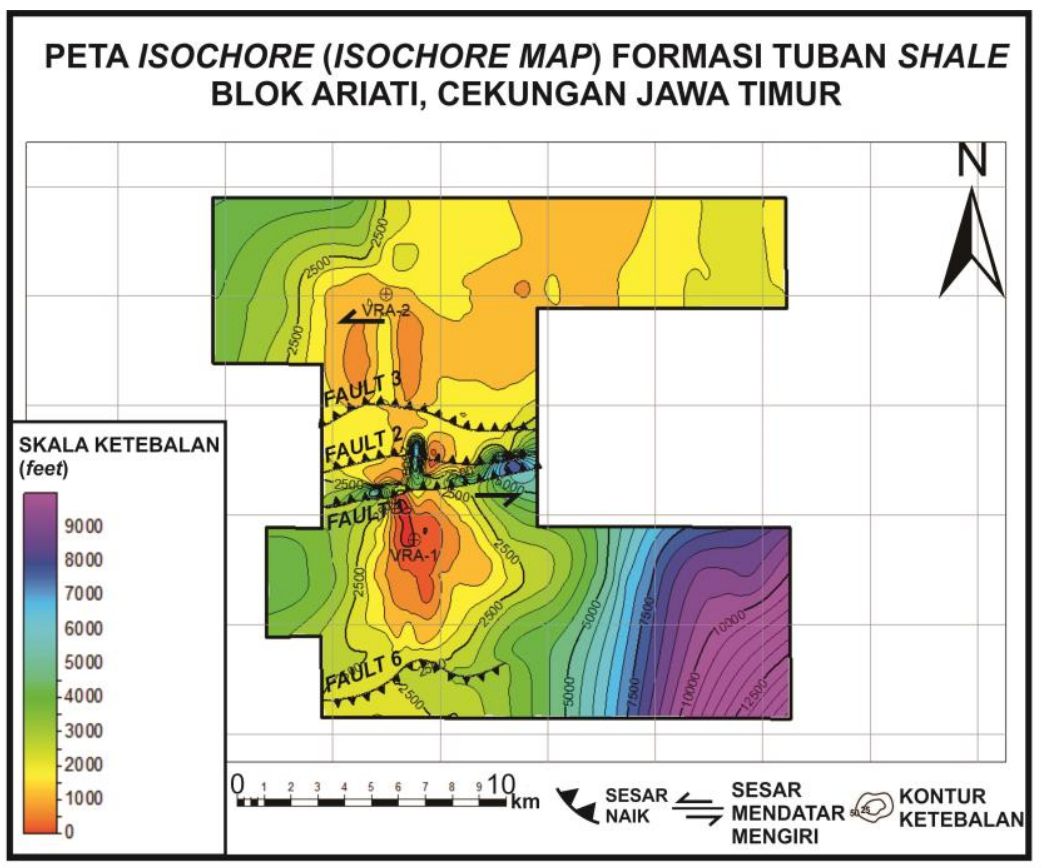

Gambar 12. Peta Isochore Formasi Tuban Shale 


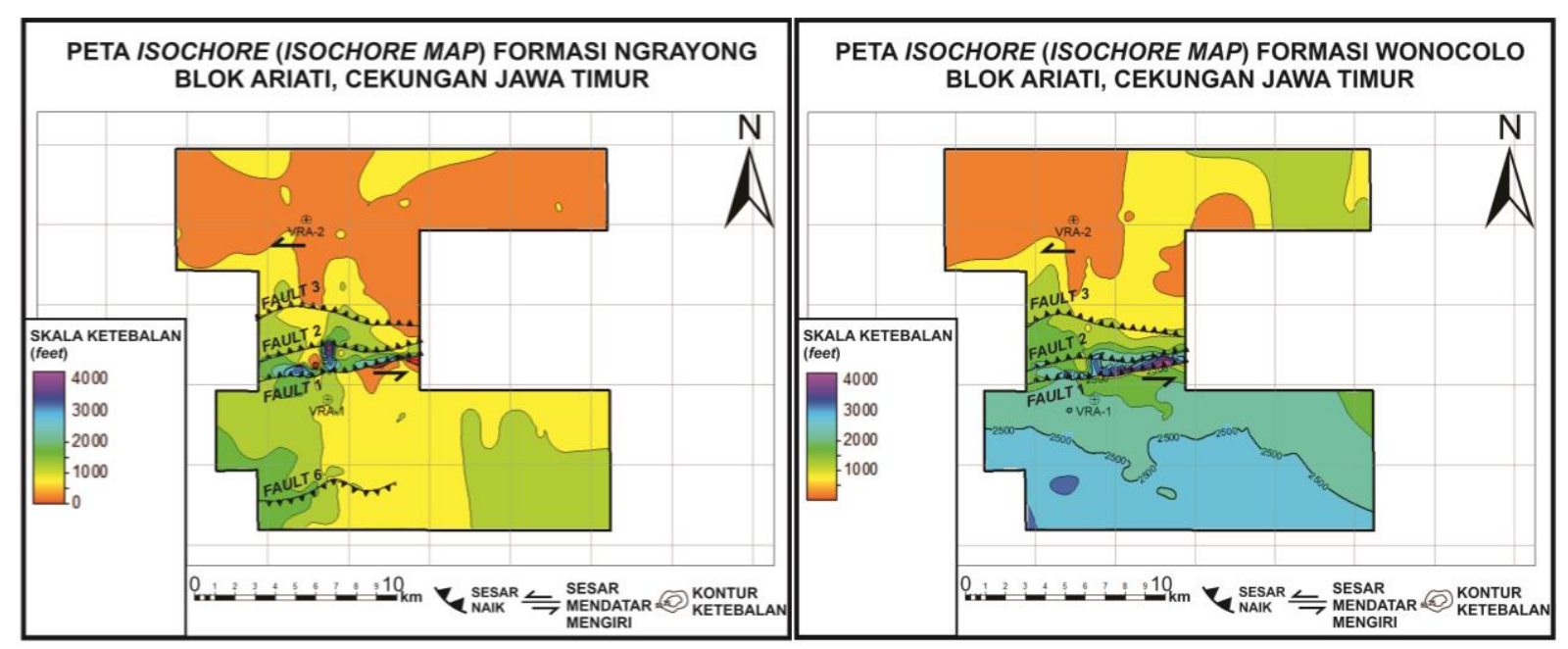

Gambar 13. Peta Isochore Formasi Ngrayong dan Formasi Wonocolo

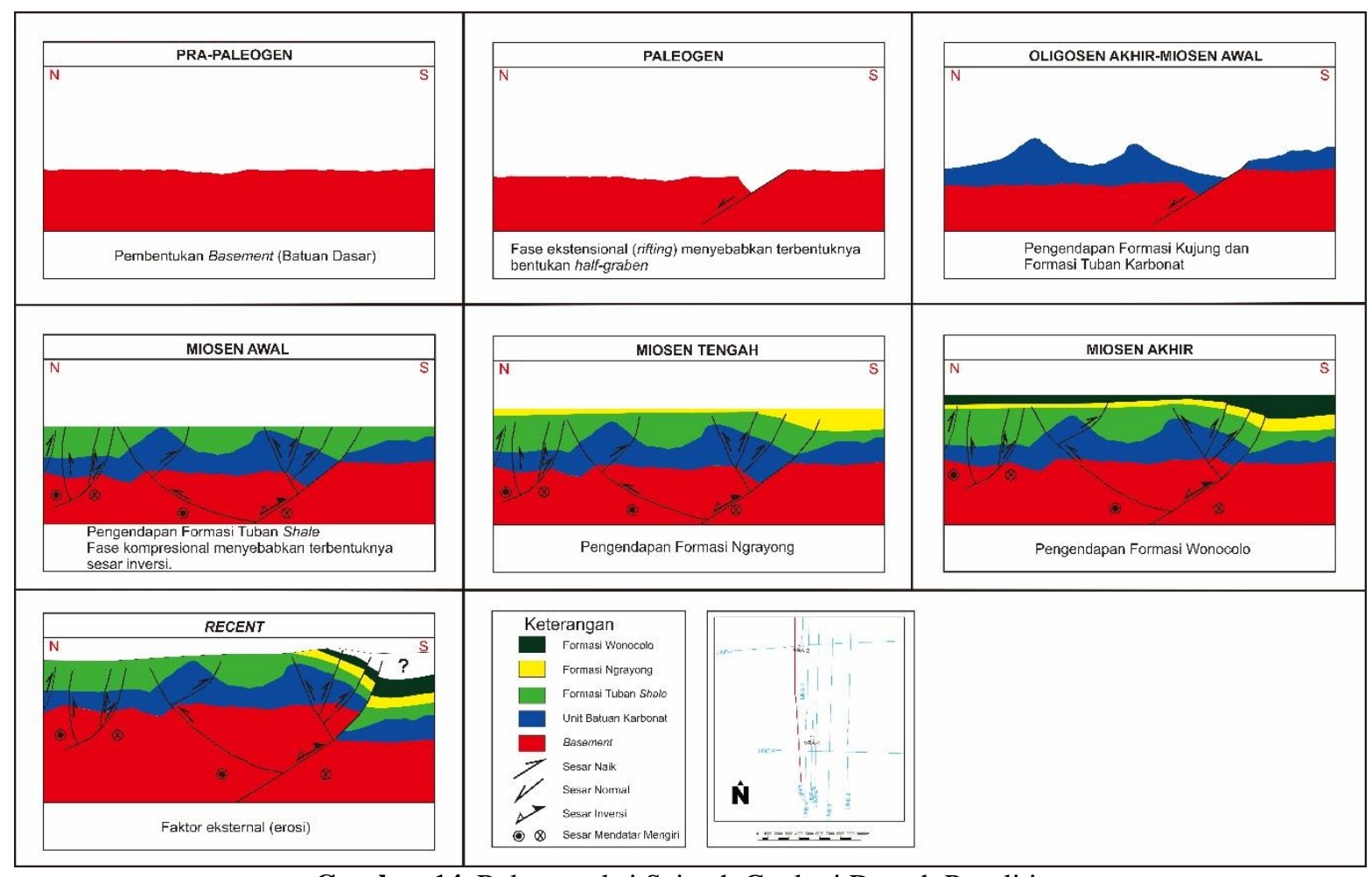

Gambar 14. Rekonstruksi Sejarah Geologi Daerah Penelitian

Adanya sedikit perbedaan ketebalan lapisan di sekitar area Fault 1 yang ditunjukkan dengan ditemukannya area yang berbeda warna kontur pada fase postrift atau syn-inversion disebabkan karena sedimen mengisi cekungan yang terbentuk akibat sesar normal pada fase ekstensional sebelumnya. Berdasarkan atas tidak adanya pola penebalan yang signifikan pada peta isochore Formasi Tuban Shale, Formasi Ngrayong, dan Formasi Wonocolo maka dapat membuktikan bahwa ketiga unit tersebut benar termasuk ke dalam fase postrift atau syninversion.

Pada fase postrift atau syn-inversion ini, diinterpretasikan terbentuk pula struktur geologi berupa sesar yaitu Fault 2, Fault 3, Fault 4, Fault 5, dan Fault 6 sebagai hasil dari fase kompresional pada daerah penelitian. Sesar ini merupakan sesar naik dengan arah timur-barat yang relatif sama dengan arah dari pola struktur Sakala. Namun, sesar ini tidak terlalu mempengaruhi geometri endapan postrift atau syn-inversion. Hal ini diinterpretasikan terjadi 
karena pergerakan sesar tidak cepat sehingga pengendapan masih dapat berlangsung dengan ketebalan yang relatif sama.

Rekonstruksi sejarah geologi dilakukan untuk mengetahui urutan kejadian geologi yang terjadi pada daerah penelitian (Gambar 14). Rekonstruksi sejarah geologi Blok Ariati, Cekungan Jawa Timur dimulai pada PraPaleogen. Sebelum periode Paleogen, diinterpretasikan pada daerah penelitian terbentuk basement atau batuan dasar. Pada periode Paleogen, sesar mayor berarah timurbarat aktif. Sesar pada periode ini merupakan hasil dari dip-slip extentional structural. Tektonik pada periode Paleogen menyebabkan terbentuknya morfologi half graben pada daerah penelitian. Pada Oligosen Akhir hingga Miosen Awal terbentuk unit batuan karbonat yaitu Formasi Kujung dan Formasi Tuban Karbonat. Formasi Kujung dan Formasi Tuban Karbonat terdiri dari litologi batugamping yang menunjukkan kenampakan carbonate build up pada penampang seismik 2D. Pada Miosen Awal, mulai terjadi inversi pada Cekungan Jawa Timur. Tektonik inversi ini berhubungan dengan subduksi yang berubah arah dari timurlautbaratdaya selama Kapur Akhir hingga Tersier Awal menjadi pola utara-selatan sampai saat ini (Satyana dan Purwaningsih, 2003). Pada Miosen Awal, terjadi transisi dari ekstensi berubah menjadi kontraksi serta terendapkan Formasi Tuban Shale. Pada Miosen Tengah, terbentuk Formasi Ngrayong dan pada Miosen Akhir terbentuk Formasi Wonocolo. Rekonstruksi pada daerah penelitian diakhiri dengan adanya faktor eksternal berupa erosi.

\section{KESIMPULAN}

Berdasarkan dari hasil analisis didapatkan kesimpulan bahwa Blok Ariati, Cekungan Jawa Timur tersusun dari Formasi Kujung dan Formasi Tuban Karbonat yang terendapkan di lingkungan pengendapan isolated platform, Formasi Tuban Shale yang terendapkan di lingkungan pengendapan isolated platform, Formasi Ngrayong hasil pengendapan lingkungan shelf, dan Formasi Wonocolo terendapkan di lingkungan pengendapan deep marine. Struktur geologi yang berkembang pada Blok Ariati, Cekungan Jawa Timur adalah sesar inversi serta sesar naik dengan arah relatif timurbarat dan diinterpretasikan mengikuti pola Sakala. Secara tektonostratigrafi, daerah penelitian terdiri dari tiga fase. Fase pertama adalah fase prerift yang menghasilkan basement atau batuan dasar. Fase kedua adalah fase synrift yang menghasilkan endapan unit batuan karbonat (Formasi Kujung dan Formasi Tuban Karbonat). Sedangkan fase ketiga adalah fase postrift atau syn-inversion yang menghasilkan endapan Formasi Tuban Shale, Formasi Ngrayong, dan Formasi Wonocolo.

\section{UCAPAN TERIMA KASIH}

Penulis mengucapkan terimakasih kepada JOB Pertamina-Petrochina East Java yang telah memberikan kesempatan penulis mengolah data Tugas Akhir dan atas bantuan berupa bimbingan yang telah diberikan.

\section{DAFTAR PUSTAKA}

Fahrudin, Nugroho, H., Winarno, T., Hasibuan, Z. H., Suprayetno, J., Firmansyah, R., Muhajir, dan Kadarusman, A., 2018. The Influence of Fault and Stress Contributed On Overpressure Mechanism For Neogen Formation (Mundu, Wonocolo, Ngrayong) East Java Basin, Indonesia. MATEC Web of Conferences 159 (2018).

Satyana, A. H. dan Purwaningsih, M. E. M., 2003. Geochemistry Of The East Java Basin: New Observations On Oil Grouping, Genetic Gas Types And Trends Of Hydrocarbon Habitats, Indonesian Petroleum Association, 29th Annual Convention Proceedings, 2003.

Sribudiyani, Muchsin, N., Ryacudu, R., Kunto T., Astono P., Prasetya, I., Sapiie, B., Asikin, S., Harsolumakso, A. H., dan Yulianto I., 2003. The Collision Of The East Java Microplate And Its Implication For Hydrocarbon Occurrences In The East Java Basin, Indonesian Petroleum Association, 29th Annual Convention Proceedings, hal. 335-346. 